Banco, Volume 1, November 2019

\title{
IMPLIKASI PENAMBANGAN PASIR DALAM MENINGKATKAN PEREKONOMIAN MASYARAKAT PADAIDI KABUPATEN PINRANG
}

\author{
Muhammad Akbar \\ IAIN Parepare \\ muhammadakbar21@iainparepare.ac.id \\ Zainal Said \\ IAIN Parepare \\ zainalsaid@iainparepare.ac.id \\ Rusnaena \\ IAIN Parepare \\ rusnaena@iainparepare.ac.id
}

\begin{abstract}
Environmental problems will arise from the interaction between human economic activities and natural resources, which starts from the demand of the population for goods and services, which in turn results in increased demand for natural resources. Through economic activities, the natural resources are exploited to produce in the form of goods and services.

In the village area, the exploitation of natural resources produces goods or services carried out through sand mining. Sand miners are one of the main economic growth factors in an area, especially in the sand mining location.

This type of research used in this thesis is a qualitative descriptive method. The data in this study were obtained from primary data and secondary data. Data collection techniques used were interviews, observation, and documentation. The data analysis technique used was qualitative data analysis.

The results of this study indicate that: 1) the economic development of the community has been able to improve the economy of the community by looking at the economic development of the community before and after the existence of sand mining 2) the implications generated in seeing the positive and negative impacts have really helped the community, such as the opening of jobs and income levels for the community, and does not have too bad an impact on the environment.
\end{abstract}

Keywords: Implementation, Economic Enhancement, mining, sand 


\begin{abstract}
Abstrak
Masalah lingkungan akan timbul dari adanya interaksi antara aktivitas ekonomi manusia dan sumberdaya alam, yang berawal dari adanya permintaan penduduk akan barang dan jasa, selanjutnya mengakibatkan meningkatnya permintaan sumber daya alam. Melalui kegiatan ekonomi, sumber daya alam tersebut diekplotasi untuk menghasilkan sebuah produk berupa barang dan jasa.

Pada daerah Kelurahan Padaidi eksplotasi sumber daya alam yang dihasilkan untuk menghasilkan barang atau jasa dilakukan melalui penambngan pasir, penambang pasir menjadi salahsatu faktor pertumbuhn ekonomi pada suatu daerah khususnya Padaidi yang merupakan lokasi penambangan pasir.

Jenis penelitian yang digunakan dalam skripsi ini adalah metode deskriptif kualitatif, data dalam penelitian ini diperoleh dari data primer dan data sekunder. Teknik pengumpulan data yang digunakan adalah wawancara, observasi, dan dokumentasi. Adapun teknik analisis datanya yaitu menggunakan analisis data kualitatif.

Implikasi dalam menentukan hasil dari penelitian menggunakan proses sehingga menhasilkan peningkatan perekonomian dengan melihat dampak baik dan buruknya serta bagaimana mengetahui perkembangan perekonomian masyarakkat sebelum dan sesudah adanya tambang pasir di Kelurahan Padaidi sebagai lokasi penelitian, dan ingin mengetahui bagaimana analisis hukum ekonomi islamnya.

Hasil penelitian ini menunjukkan bahwa:1) perkembangan ekonomi masyarakat sudah dapat meningkatkan perekonomian masyarakat dengan melihat perkembangan ekonomi masyarakat sebelum dan sesudah adanya pertambangan pasir 2) implikasi yang dihasilkan dalam melihat dampak positif dan negatifnya sudahh sangat membantu masyarakat, seperti terbukanya lapangan pekerjaan dan tingkat pendapatannya bagi masyarakat, dan tidak terlalu berdampak buruk pada lingkungan 3)standar produksi jual beli berdasarkan ekonomi islam pada pertambangan yaitu sudah dinilai dengan baik oleh masyarakat, serta tidak terlalu berdampak pada lingkungan dan tingkat kemakmuran masyarakat sangat baik
\end{abstract}

Kata Kunci: Implikasi, Peningkatan ekonomi, Tambang pasir

\title{
A. Pendahuluan
}

Indonesia merupakan negara yang sedang berkembang, baik itu dalam hal politik maupun perkembangan ekonomi. Sumberdaya alam yang terkandung di dalamnya banyak dan berpotensi. Pemanfaatan sumberdaya alam khususnya bahan galian industri yang berada di berbagai daerah mempengaruhi perkembangan pertumbuhan ekonomi indonesia. Kegiatan pemanfaatan sumberdaya alam secara besar-besaran memang berdampak baik terhadap pertumbuhan ekonomi, namun sebaliknya efek negatif terhadap lingkungan juga timbul. Maka dari itu, suatu kegiatan yang memanfaatkan unsur alam harus dibarengi dengan suatu tindakan konservasi atau dengan melakukan kegiatan yang berwawasan lingkungan agar lingkungan agar lingkungan tersebut dapat berkelanjutan.

Semua kekayaan bumi, baik biotik maupun abiotik, yang dapat dimanfaatkan untuk kesejehteraan manusia merupakan sumber daya alam hayati, sedangkan faktor abiotik lainnya merupakan sumber daya alam hayati, sedangkan faktor abotik lainnya merupakan sumber daya alam nonhayati. Pemanfaatan sumber daya alam harus diikuti oleh pemeliharaan dan pelesterian karena sumber daya alam bersifat terbatas. Pentingnya pelestarian lingkungan dilakukan karena dengan kegiatan pelestarian tersebut terjamin pula pasokan bahan baku industri sehingga pertumbuhan ekonomi akan terus berlangsung.

Masalah lingkungan akan timbul dari adanya interaksi antara aktivitas ekonomi manusia dan sumberdaya alam, yang berawal dari adanya permintaan penduduk akan barang dan jasa, selanjutnya mengakibatkan meningkatnya permintaan sumber daya alam. Melalui kegiatan ekonomi, sumberdaya alam tersebut dieksploitasi untuk menghasilkan sebuah produk berupa barang atau jasa. Jika kalau yang terjadi adalah kegiatan eksploitasi 
sumberdaya alam yang semakin meningkat dan dilakukan terus-menerus tanpa diikuti oleh usaha lain untuk melestarikannya maka daya dukung lingkungan akan menjadi berkurang ${ }^{1}$.

Tambang pasir di Kabupaten Pinrang sendiri banyak penambang yang memanfaatkan sumber daya alam untuk kebutuhan ekonomi di berbagai daerah, khususnya di Kelurahan Padaidi Kabupaten Pinrang, penambangan pasir di Padaidi biasanya mempekerjakan orang orang dari luar daerah maupun dari dalam daerah, namun kegiatan pemanfaatan sumber daya alam ini secara besar besaran memang berdampak baik terhadap pertumbuhan ekonomi, namun sebaliknya terhadap efek lingkungan yang ditimbulkan. Maka dari itu penulis akan melakukan observasi dan wawancara di wilayah pertambangan untuk memperoleh data dan hasil penelitian untuk peningkatan perekonomian masyarakat Padaidi.

Olehnya, tujuan penelitian ini adalah menguraikan Implikasi Penambangan Pasir dalam Meningkatkan Perekonomian Masyarakat Padaidi Kabupaten Pinrang (Analisis Hukum Ekonomi Islam).

\section{B. Diskusi dan Pembahasan}

\section{Kondisi Ekonomi Masyarakat Padaidi'}

Pertumbuhan ekonomi dapat didefinisikan sebagai perkembangan kegiatan dalam perekonomian yang menyebabkan barang dan jasa yang diproduksikan dalam masyarakat bertambah. Masalah pertumbuhan ekonomi dapat dipandang sebagai masalah makroekonomi dalam jangka panjang. Dari stau periode ke periode lainnya, kemampuan suatu negara untuk menghasilkan barang dan jasa akan meningkat.

Pertumbuhan ekonomi dapat terlihat dari berbagai faktor. Salah satu yang menjadi faktor khusus peningkatan perekonomian adalah dengan berdirinya suatu usaha yang dapat menunjang perekonomian. Pada Kelurahan Padaidi, salah satu usaha yang menunjang perekonomian suatu daerah, khususnya Kelurahan Padaidi. Berikut diuraikan pertumbuhan ekonomi sebelum dan sesudah adanya penambang pasir di Kelurahan Padaidi.

\section{a. Sebelum Adanya Penambang Pasir}

Masyarakat Kelurahan Padaidi, adalah masyarakat yang dimana mayoritas masyarakatnya adalah petani dan pekebun, dan sebelum adanya penambangan pasir banyak dari masyarakat utamanya remaja yang putus sekolah dan menjadi pengangguran dan begitupun dari pekerja petani dan pekebun kebanyakan dari mereka tidak terlalu berfokus pada pekerjaanya karena lamanya musim panen. Dilihat dari pertumbuhan ekonomi, pekerjaan yang memerlukan aktivitas penuh seharian dalam mengumpulkan modal untuk meningkatkan perekonomian masyarakat Padaidi kurang. Sebagaimana hasil kutipan hasil wawancara dengan bapak Abd. Latif sebagai berikut:

"riolo mairo, wattunna degagapa pakkassikang e magalung manang mi na madara tau e, jadi makurang ladda panghasilan. ${ }^{2}$

Berdasarkan hasil wawancara, dapat dipahami bahwa mata pencaharian masyarakat Padaidi hanya bergantung pada petani dan pekebun, jadi perekonomian masyarakat sedikit banyaknya di pelopori oleh hasil panen sawah dan kebun.

${ }^{1}$ repository.upi.edu/677/4/S_GEO_0901041_CHAPTER1.pdf

${ }^{2}$ Abd latif, buruh tambang pasir Kel. Padaidi Kec. Mattiro bulu Kab. Pinrang, wawancara oleh penulis di lokasi pertambangan pasir Kel. Padaidi, 14 Agustus 2017

Banco, Volume 1, November 2019 


\section{b. Sesudah Adanya Penambamg Pasir}

Penambangan pasir di Kelurahan Padaidi sangat membantu perekonomian masyarakat sejak berdirinya pada tahun 2014, dengan melihat segi pengurangan jumlah pengangguran di sebagian masyarakat Padaidi yang bekerja sebagai penambang, baik itu remaja maupun orang tua. Sebagaian besar pengangguran yang berkurang karena bekerja di penambangan pasir adalah tenaga kerja laki-laki. Pekerja laki laki di tambang pasir di Kelurahan Padaidi memiliki banyak penambang yaitu sebanyak 15 buruh tambang sebagai pekerja tetap dan biasanya itu bertambah sesuai banyaknya permintaan pelanggan. Sebagaimana yang di ungkapkan bapak sabir sebagai buru tambang sebagai berikut:

"wattunna angka ie akkassikang e maega pattambang majama mappammula kallolo lattu tomatoa majama manang . apana ie akkassikangnge makanja modalana"3

Berdasarkan hasil wawancara, dapat dipahami bahwa peningkatan penghasilan masyarakat yang dahulunya menjadi petani dan pekebun, sudah ada yang bekerja di penambangan Pasir di Kelurahan Padaidi untuk menambah pendapatannya dan menjadikannya sebagai pekerjaan sampingan. Adapun masyarakat yang bekerja di tambang pasir itu sebagian pengangguran. Setelah menjadi pekerja di penambangan pasir penghasilan dari penjualan pasir dapat dipastikan tiap hari pasti ada. Begitu juga dengan masyarakat yang dahulunya menjadi buruh tani, sekarang penghasilan mereka lebih besar dengan menjadi penambang. Mereka mengatakan bahwa penambangan pasir sangat membantu ekonomi mereka. Sebagian kepala keluarga merasa tenang karena dengan bekerja di penambangan pasir ada penghasilan yang mereka peroleh untuk menghidupi keluarga mereka. Sebelumnya mereka adalah pengangguran.

\section{Peningkatan Perekonomian Masyarakat melalui Penambangan Pasir}

\section{a. Pendapatan}

Melihat maraknya pemesanan dari berbagai daerah dalam memanfaatkan pasir, para buruh tambang sangat berpeluang dalam meningkatkan ekonomi karena banyaknya pesanan atau mobil truk yang masuk itu merupakan salah satu keuntungan pekerja tambang yang bekerja sebagai buruh karena dalam melihat pendapatanya itu tergantung dari banyaknya pemesanan yang masuk. Sistem yang digunakan di dalam tambang pasir ini yaitu berkelompok dan bergiliran, setiap kelompok itu terdiri dari 3 orang bagian yang menaikkan pasir ke truk dan dalam 1 hari itu terdiri dari 4 kelompok yeng beraktivitas dan pemompanya sebanyak 3 orang dan upah yang dihasilkan dihitung dari mobilnya jika 1 mobil itu upahnya 14.000 per orang. Jika dalam 1 harinya ada 30 mobil dan dibagi 4 kelompok, jadi upah dalam sehari bagi buruh adalah Rp 98.000 dikali 30 hari sama dengan Rp 1.980.000. Itu adalah gaji perbulannya jika dalam satu hari itu terdapat 30 mobil. Jadi dalam menentukan pendapatannya itu tidak pasti. Sebab mobil truk yang masuk itu kadang kurang kadang lebih sesuai dari pemesanannya.

Pertambangang di Kelurahan Padaidi ini sudah memiliki surat izin yang langsung di pegang oleh pemiliknya dan tidak terlepas dari adanya pajak yang ada. Namun belum adanya ketegasan dari pemerintah daerah melihat tingginya kriminalitas dan kerusakan jalan yang yang dihasilkan dari tampang pasir yang berlokasi di Kelurahan Padaidi membuat mesyarakat yang ada di sekitar lokasi penambangan pasir merasakan dampaknya utamanya petani dan masyarakat sekitar. Saat ini diperlukan adanya kebijakan daerah yang sesuai dengan peraturan nasional terhadap pengelolaan penambangan

\footnotetext{
${ }^{3}$ sirajuddin, buruh tambang pasir Kel. Padaidi Kec. Mattiro bulu Kab. Pinrang, wawancara oleh penulis di lokasi pertambangan pasir Kel. Padaidi, 14 Agustus 2017
} 
pasir di Kelurahan Padaidi sehingga sumber daya alam berupa pasir dapat meningkatkan kesejahteran masyarakat Padaidi pada umumnya.

Berbagai kepentingan dalam kegiatan pertambangan harus pula memperhatikan kepentingan masyarakat hukum adat telah memiliki hak kepemilikan terhadap lahan di sekitar petambangan. Negara melalui Pemerintah memiliki kewajiban hukum untuk menghormati hak-hak yang dimiliki masyarakat hukum adat yang didasarkan pada hak-hak asal usul.

\section{b. Usaha}

Tambang pasir di Kelurahan Padaidi Kec. Mattiro bulu Kabupaten Pinrang telah beroperasi sejak 2014, dan tambang ini mempunyai 15 buruh tambang sebagai pekerja tetap dan kadang lebih, dengan usaha yang dijalankan sang pemilik banyak dari masyarakat Padaidi yang bekerja sebagai buruh untuk menambah pendapatannya baik itu dari kalangan remaja maupun orang tua

\section{Implikasi Penambangan Pasir dalam Meningkatkan Perekonomian Masyarakat di Kelurahan Padaidi Kabupaten Pinrang}

\section{a. Dampak Positif}

\section{1) Meningkatkan pendapatan masyarakat}

Kegiatan penambangan pasir di Kelurahan Padaidi memberikan dampak terhadap tingkat pendapatan masyarakat. Hal ini terlihat pada masyarakat pengangguran mengakui bahwa adanya kegiatan penambang pasir memberikan keuntungan yang sangat besar sehingga bisa mencukupi kebutuhan hidupnya.

Pada dasarnya, tingkat kehidupan ekonomi seseorang atau masyarakat khususnya di Kelurahan Padaidi ditentukan oleh kesempatannya memperoleh sumber pendapatan, kesempatan kerja, dan kesempatan berusaha. Namun pada kenyataannya, masyarakat dihadapkan pada masalah-masalah yang menimbulkan tingkat ekonominya rendah diantaranya seperti sulitnya mendapatkan pekerjaan. Kesempatan kerja di Desa Padaidi semakin terbuka setelah adanya kegiatan penambangan pasir yang memberikan dampak positif bagi warga sekitar sehingga dapat meningkatkan perekonomian masyarakat sebagaimana yang diungkapkan bapak nasir sebagai buruh tambang sebagai berikut:

"maega pengangguran aria kampokku maega to kasina magalung tapi galung cikami, tapi wattunna angka ie tambang e angkana kasina tamba tambai panghasilanna pagalungnge sibawa tau manganggur $\mathrm{e}^{4,}$

Sebagaimana maksud bapak nasir sebagai buruh yaitu sejak adanya tambang pasir para pengangguran dan petani bisa menambahkan pendapatannya di dalam tambang pasir itu, serta sebagai sarana membuka lapangan pekerjaan untuk masyarakat Padaidi. Hal ini sesuai dengan perda Kabupaten Pinrang Nomor 13 tahun 2012 Tentang Pengelolaan Pertambangan Mineral Dan Batubara, yang berbunyi : bahwa pertambangan mineral dan batubara merupakan salah satu jenis kekayaan alam tak terbarukan, mempunyai peranan penting dalam meningkatkan kesejahteraan masyarakat dan perekonomian daerah, karena itu pengelolaannya harus dilakukan secara efisien, optimal, berkeadilan, dan berwawasan lingkungan berkelanjutan sesuai perundang-undangan.

\footnotetext{
${ }^{4}$ Nasir, buruh tambang pasir Kel. Padaidi Kec. Mattiro bulu Kab. Pinrang, wawancara oleh penulis di lokasi pertambangan pasir Kel. Padaidi, 13 Agustus 2017
} 


\section{2) Pemanfaatan sumber daya alam}

Masyarakat di Indonesia tidak terlepas yang namanya sumber daya alam seperti pasir dan sebagainya yang merupakan bahan pokok pembangunan, yang sangat membantu manyarakat dan dalam memenuhi kebutuhannya. Pemanfaatannya penambang pasir sangat berpengaruh atas keberhasilannya pasir yang digaruk langsung dari tambangnya yang merupakan modal bagi masyarakat sekitar.

\section{b. Dampak Negatif}

Para penambang pasir di Kelurahan Padaidi yang telah mendapatkan pasir biasanya meggunakan alat atau mesin mesin berat seperti mobil pengangkut. Mobil yang mengangkut pasir tersebut tentu menggunakan alternatif jalan raya yang tentunya akan membuat jalan raya semakin rusak dikarenakan berat beban pada kendaraan angkut tersebut melebihi kapasitas yang ditentukan. Selain itu, pengangkutan bobot beban yang berlebihan dapat menimbulkan kecelakaan lalu lintas terutama di jalur utama. Kendaraan yang melintas di jalur utama biasa menggunakan kecepatan diatas $60 \mathrm{~km} / \mathrm{jam}$ untuk menempuh waktu yang ditargetkan. Itulah kenapa di jalan utama kendaraan tidak diizinkan untuk membawa beban yang melebihi kapasitas seperti truk pembawa pasir. Selain itu, juga kendaraan yang membawa beban berat bisa menimbulkan kemacetan yang cukup parah.

Jadi jika dibandingkan dampak positif dengan dampak negatif sesuai hasil wawancara, dampak positif lebih dominan di dalam penambangan pasir itu karena di sekian banyaknya masyarakat penambang dari Kelurahan Padaidi bekerja sebagai buruh pasir dibandingkan dampak negatif yang dihasilkan oleh tambang pasir itu yang tidak terlalu banyak dampaknya terhadap lingkungan. Sebagaimana yang diungkapkan oleh ibu sumarni sebagai masyarakat Padaidi sebagai berikut:

"yako iritai dampana ciddi bawang iro bawang lalang e. Nasolangi apana otoe tole tama mala kassi aria akkassikangnge jadi nasessai kasi pagalungge sibawa padara"

Sebagaimana yang telah diungkapkan oleh ibu sumarni bahwa dampak yang di hasilkan dari tambang itu tidak terlalu banyak.

\section{Analisis Hukum Ekonomi Islam terhadap implikasi penambangan pasir dalam meningkatkan perekonomian masyarakat Kelurahan Padaidi}

Kelurahan Padaidi Kabupaten Pinrang merupakan salah satu Kelurahan yang letaknya berada di sekitar persawahan, dengan kondisi tanah yang subur membuat mayoritas penduduk desa Ngablak memilih menggantungkan hidupnya sebagai petani. bahkan tidak sedikit pula penduduk Kelurahan Padaidi yang sudah memiliki profesi lain namun mereka masih tetap bertani untuk menggarap tanahnya. Mayoritas penduduk Kelurahan Padaidi berprofesi sebagai petani dan pekebun namun tidak semua penduduk masyarakat Padaidi memiliki tanah dan bertani. Kondisi inilah yang membuat penduduk memutar otak guna tetap bekerja. Dari situlah masyarakat Padaidi menemukan tambang pasir sebagai acuan untuk menambah biaya ekonomi masyarakat. Para pekerja atau buru pasir di sana sangat bersyukur karena adanya pekerjaan tambahan bagi petani dan masyarakat di sekitarnya. Masyarakat dari luar Padaidi juga datang untuk menambah biaya ekonomi keluarga mereka.

Transaksi yang umum dilakukan adalah jual beli atau mendistribusikannya ke pelanggan dengan cara

\footnotetext{
${ }^{5}$ Sumarni, masyarakat Kel. Padaidi Kec. Mattiro bulu Kab. Pinrang, wawancara oleh penulis di lokasi jalan masuk pertambangan pasir Kel. Padaidi, 13 Agustus 2017
} 
a. Melakukan percakapanM atau transaksi jual beli kepada supir truk dan memberitahu pemilik tambang untuk pemesanan melalui hand phone atau komunikasi jarak jauh

b. Menerima tanda jadi atau tanda sah kepada kedua belah pihak sebelum di distribusikan

c. Pendistribusian dilakukan dengan menggunakan mobil truk

Sebagaimana yang diungkapkan oleh bapak irwan sebagai pemilik sebagai berikut:

"biasanya kalao kita mau kirimkan barang kepelanggan itu biasanya mereka menelpon supir truk dan supir truk itu memberi tahu kepada kami bahwa ada yang ingin memesan pasir kemudian diantarkan pakai truk ${ }^{6,}$

Melihat tiga cara proses pendistribusiannya tersebut dengan cara bertransaksi, sebetulnya masih belum bisa memuaskan konsumen. Penggunaan takaran itu berbeda-beda karena menggunakan mobil truk yang berbeda pula. Belum lagi pasir yang dikirimkan itu bersih atau tidak dari sampah seperti bangkai kayu atau kerikil dan tentunya itu sangat tidak memuaskan bagi pelanggan. Dan di dalam al quran juga di sebutkan dalam Qs.al nisa:29-30

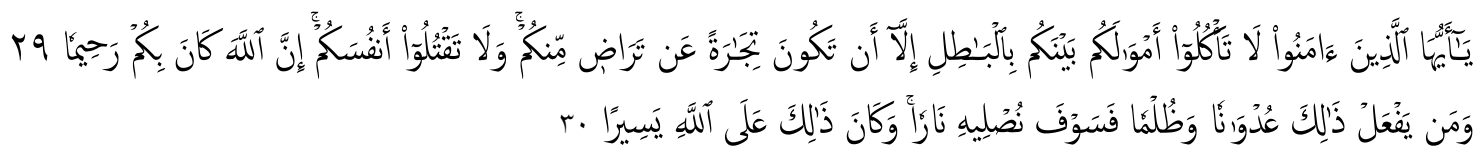

Terjemahannya

29. Hai orang-orang yang beriman, janganlah kamu saling memakan harta sesamamu dengan jalan yang batil, kecuali dengan jalan perniagaan yang berlaku dengan suka sama-suka di antara kamu. Dan janganlah kamu membunuh dirimu; sesunggubnya Allah adalah Maha Penyayang kepadamu

30. Dan barangsiapa berbuat demikian dengan melanggar hak dan aniaya, maka Kami kelak akan memasuk.kannya ke dalam neraka. Yang demikian itu adalah mudah bagi Allah.

Ayat di atas bahwa menegaskan bahwa segala aturan syari'ah, baik yang berkaitan dengan urusan materi atau pun kehidupan berkeluarga, telah ditetapkan Allah SWT untuk memberi keringanan bagi umat. Ayat tersebut juga memberikam bimbingan tentang syari'ah yang berkaitan dengan cara transaksi yang benar. Setiap umat mesti menghormati milik orang lain, jangan sampai mengambilnya dengan cara yang salah. Transaksi yang benar adalah dengan cara jual beli yang saling menguntungkan dan memberikan kepuasan bagi semua pihak

Pertambangan yang ada di Kelurahan Padaidi ini merupakan satu dari sekian banyak konsumen dalam pengambilan bahan bangunan yaitu pasir yang dijadikan sebagai campuran dalam pembuatan bangunan. Dalam memanfaatkan tanah dan dijadikan sebagai lokasi tambang. Hal ini menurut penulis perlu adanya pembahasan tersendiri guna mendapatkan kepastian hukum sehingga kedepannya tidak akan terjadi pelanggaran-pelanggaran hukum yang serupa dalam kehidupan masyarakat. Dalam pelaksanaan jual beli batu dan pasir di lahan Kelurahan Padaidi dan penulis menganalisis sebagai berikut:

Apabila kita lihat sekarang ini, perilaku konsumtif masyarakat sangat tinggi, salah satunya yaitu di bidang pembangunan seiring dengan semakin meningkatnya aktifitas pembangunan di daerah daerah, seperti pembangunan perumahan, ruko-ruko maupun properti-properti lainnya. Oleh karenanya, kebutuhan akan bahan baku bangunan seperti batu dan pasirpun semakin meningkat. Faktor inilah

\footnotetext{
${ }^{6}$ Irwan, pemilik tambang pasir Kel. Padaidi Kec. Mattiro bulu Kab. Pinrang, wawancara oleh penulis di lokasi pertambangan pasir Kel. Padaidi, 13 Agustus 2017
}

Banco, Volume 1, November 2019 


\section{Muhammad Akbar, Zainal Said dan Rusnaena}

yang memicu masarakat untuk menambang pasir di alam secara besar-besaran, guna memenuhi permintaan konsumen yang begitu besar.

Besarnya peningkatan permintaan bahan baku bangunan oleh konsumen, namun tidak diimbangi dengan ketersediaan bahan baku di alam. Pengelolaan Sumber daya alam yang tidak bijak dengan melakukan penambangan secara besar-besaran oleh para penambang akan berdampak pada semakin menipisnya ketersediaan bahan baku di alam. Padahal seperti yang kita ketahui bahwa pasir dan air merupakan jenis Sumber daya alam yang tidak dapat diperbaharui. Apabila pemanfaatan sumber daya alam tidak dilakukan dengan bijak dan dilakukan secara besar-besaran tanpa memperdulikan aspek keberlangsungan dari sumber daya alam itu sendiri, maka cepat atau lambat keberadaan sumber daya alam berupa pasir di alam akan habis. Hal ini juga di kecam oleh MUI yang mengeluarkan fatwa tentang pertambangan yang berbunyi: pertambangan boleh di lakukan sepanjang untuk kepentingan kemaslahatan umum, tidak mendatangkan kerusakan, dan ramah lingkungan.

Maksud dari fatwa MUI adalah pelaksanaan pertambangan harus ramah lingkungan dan tidak berlebihan karena akan berdampak bagi masyarakat yang berada pada suatu lingkungan atau Negara bahkan bagi bumi. Hal ini sesuai dengan hadits Rasulullah SAW

Dari Sa'id ibn Yazid ra ia berkata: Saya mendengar Rasulullah saw bersabda: Barang siapa melakukan kezhaliman terhadap sesuatu pun dari bumi, niscaya Allah akan membalasnya dengan borgolan tujuh kali bumi yang ia zhalimi. (HR. Bukhari) ${ }^{7}$

Sehubungan dengan hadis tersebut, bahwasanya di dalam pertambangan dilarang merusak lingkungan karena berdampak pada masyarakat, kecuali tambang itu di manfaatkan sumber daya alamnya untuk dikelola dengan baik dan tidak merusak alam disekitarnya.

Berbeda dengan pada kegiatan pertambangan yang terjadi di Padaidi, pertambangan yang dilakukan sebagaimana mestinya. Tidak berlebihan, dan malah berdampak pada penginkatan perekonomian bagi masyarakat setempat.

Pada prinsipnya, kegiatan produksi terkait seluruhnya dengan syariat Islam, di mana seluruh kegiatan produksi harus sejalan dengan tujuan dari konsumsi itu sendiri. Konsumsi seorang muslim dilakukan untuk mencari falah (kebahagiaan), demikian pula produksi dilakukan untuk menyediakan barang dan jasa guna falah tersebut.

Pertambangan pasir di Kelurahan Padaidi sangat meningkat drastis karena banyaknya permintaan dari konsumen yang membutuhkan pasir dalam memenuhi kebutuhannya terutama dalam pembangunan. Begitu pun dengan cara produksinya dalam tahap pengelolaaan dan pendistribusian itu sudah terbilang jujur, dilihat dari positifnya penilaian dari masyarakat mengenai produksi jual beli pasir di Kelurahan Padaidi Kec. Mattiro bulu Kabupaten Pinrang

Pertambangan pasir di Kelurahan Padaidi sangatlah sederhana dan tidak terlalu luas sehingga penataan tambangnya sangat jelas dibandingkan dengan tambang yang ada di daerah lain sangat membebani masyrakat sekitar karena banyaknya longsor. Tambang pasir di Kelurahan Padaidi tidak terlalu memiliki dampak buruk terhadap lingkungan, namun sebaliknya tambang di Kelurahan Padaidi lebih mementingkan tingkat ekonominya dan tidak terlalu merusak lingungan.

Produksi dimaksudkan untuk memenuhi kebutuhan individu dan masyarakat serta mencapai kemakmuran. Kebutuhan yang harus dipenuhi harus berdasarkan prioritas yang ditetapkan agama, yakni terkait dengan kebutuhan untuk tegaknya akidah/agama, terpeliharanya nyawa, akal dan keturunan/kehormatan, serta untuk kemakmuran material.

\footnotetext{
${ }^{7}$ Https: / / mui-lplhsda.org/ fatwa-majelis-ulama-indonesia-nomor-22-tahun-2011-tentang-pertambangan-ramahlingkungan/
} 
Produksi tambang pasir di Kelurahan Padaidi sangat meningkat drastis sejak berdirinya tambang pada tahun 2014 ini, para pekerja buruh pasir ini mengungkan banyaknya mobil truk yang keluar masuk itu mempengaruhi tingkat ekonomi dengan baik serta pemanfaatan sumber daya alamnya yang dijadikan sarana pembangunan.

\section{Kesimpulan}

1. Mata pencaharian masyarakat Padaidi pada masa sebelum adanya penambang pasir hanya bergantung pada petani dan pekebun sehingga perekonomian masyarakat sedikit banyaknya tergantungg oleh hasil panen sawah dan kebun. Sedangkan setelah adanya penambang pasir, penghasilan masyarakat yang dahulunya menjadi petani dan pekebun, sudah ada yang bekerja di penambangan Pasir untuk menambah pendapatannya dan menjadikannya sebagai pekerjaan sampingan. Hal ini tentu berdampak pada pertumbuhan ekonomi karena terbukanya lapangan pekerjaan selain sawah dan kebun.

2. Implikasi penambangan pasir dalam meningkatkan perekonomian masyarakat di Kelurahan Padaidi, sudah memberikan dampak yang baik terutama dalam peningkatan perekonomian dan terbukanya lapangan pekerjaan baru, namun tambang pasir ini tidak terlepas dari dampak negatifnya yaitu kerusakan jalan di wilayah area tamang pasir di Kelurahan Padaidi.

3. Standar produksi jual beli berdasarkan ekonomi islam pada pertambangan yaitu sudah dinilai dengan baik oleh masyarakat, serta tidak terlalu berdampak pada lingkungan dan tingkat kemakmuran masyarakat sangat baik 


\section{Muhammad Akbar, Zainal Said dan Rusnaena}

\section{Daftar Pustaka}

Al-Assal, Muhammad Ahmad dan Abdul Karim Ahmad Fathi. 1999. sistem prinsip dan tujuan ekonomi islam. (Cet 1, CV Pustaka Setia Bandung ).

Bahri, Andi.2013, Ekonomi Islam.(Parepare:STAIN Parepare).

Departemen Agama RI. 2010. Al-Qur'an dan Terjemahanny. (Cet.1, Jakarta:CV Darus Sunnah).

Departemen Pendidikan Nasional. 2008. KBBI Edisi Keempat. (Ed.4. Cet. 1; Jakarta: PT Gramedia Pustaka Utama).

Emzir. 2011. Metode Penelitian Kualitatif Analisis Data. (Ed. 1; Jakarta:Rajawali Press).

Fauzia, Ika Yunia. 2014. Prinsip Dasar Ekonomi Islam Perspektif Maqashid al-Syaria'ah. (Cet.1, Ed.1, Jakarta:Prenadamedia Group).

Harun, Rasyid. 2000. Metode Penelitian Kualitatif Bidang Ilmu Sosial Agama. (Pontianak:STAIN Pontianak).

Suprayogo, Imam dan Tobroni. 2010. Metode Penelitian Sosial Agama. (Bandung: Remaja Rosdakarya).

Irawan, Soehartono. 2004. Metode Penelitian Sosial. (Bandung:PT.Remaja Rosdakarya).

Mannan, Abdul. 1995. Teori dan Praktek Ekonomi Islam. (Yogyakarta:PT. Dana Bhakti Wakaf).

Mardalis. 2004. Metode Penelitian: Suatu Pendekatan Proposal. (Cet.7; Jakarta: Bumi Aksara).

Munawar, Iqbal. Financing Economic Development. dalam buku Abul Hasan Muhammad Sadeq.

Nasution, Edwin Mustafa Dkk. 2010. Pengenalan Eksklusif Ekonomi Islam. (Ed.1, Cet. 3, Jakarta:Kencana).

Ngurah Agung, I Gusti dkk. 2008. Teori Ekonomi Mikro Suatu Analisis Produksi Terapan,(Ed 1 Cet 1 ,Jakarta:PT Raja Grafindo Persada).

P3EI Universitas Islam Indonesia. 2012. Ekonomi Islam (Cet.4; Jakarta:Kharisma Putra Utama).

Salim. 2010. Hukum Pertambangan Indonesia, (Cet. ke-5; Jakarta:Rajawali Pers).

Sasmoko. 2004. Metode Penelitian. (Jakarta:UKI Press)

Sugiyono. 2008. Metode Penelitian Kualitatif Kuantitatif dan R\&D. (Bandung: Alfabeta).

, 2010, Memahami Penelitian Kualitatif, ( Cet. VI; Bandung:Alfabeta)

Suharsimi, Arikunto. 2000. Manajemen Penelitian. (Cet. 4; Jakarta: PT. Rineka Cipta).

Sukinno, Sadono. 2012. mikero ekonomi teori pengantar. (Ed. 3 Cet 27, Jakarta:Rajawali pers).

Suyanto, Bagong. 2007. Metode Penelitian Sosial: Berbagai Alternatif Pendekatan. (Ed.2, Cet.3; Jakarta:Kencana)

Tim Penyusun. 2013. Pedoman Karya Ilmiah (Makalah dan Skripsi). Edisi Revisi (Parepare: STAIN Parepare).

\section{Referensi Internet}

Arti-definisi-pengertian.info/pengertianTambang/

Digilib.unila.ac.id/13003/3/BAB\%20II.pdf 
Https:/ / mui-lplhsda.org/fatwa-majelis-ulama-indonesia-nomor-22-tabun-2011-tentang-pertambangan-ramah-lingkungan/

Http://www.pengertianmenurutparaahli.com/pengertian-implikasi/

Http://cahipasaja.blogspot.co.id/2015/06/makalah-penambangan-pasir-bengawan- solo_71.html

Http://www.pengertianmenurutparaahli.net/pengertian-implikasi-dan-contohnya/

Http://www.pinrangkab.go.id/berita-591-PROSEDUR-IZIN-TAMBANG-DISOSIALISASIKAN

Http://jurnalapapun.blogspot.co.id/2015/02/pengertian-produksi-menurut-para-ahli.html

Https://vauzidotnet.wordpress.com/2014/03/07/pengertian-distribusi-secara-umum-dan-menurut-para-ahli/

Http:/ /ayuismaini.blogspot.co.id/2013/12/materi-distribusi.html

http://eprints.uny.ac.id/11926/1/Makalah\%20Suhartini\%20UNY.pdf

Repository.upi.edu/677/4/S_GEO_0901041_CHAPTER1.pdf

Repository.fisip-untirta.ac.id/26/1/skripsi_KIKI_RIZKI_DESIANTI-2.pdf 